\title{
STUDY ON SYNTHESIS AND ANTIMICROBIAL ACTIVITIES OF SOME MICHAEL-TYPE ADDITION COMPOUNDS
}

\author{
BAZI MICHAEL TIPİ KATIM ÜRÜNLERININ SENTEZ ÇALIŞMASI VE ANTIMIIKROBIYYAL \\ AKTIVITELERI
}

\section{Gül BAYRAM ${ }^{*}$ (D), Abdoul NZEYIMANA ${ }^{2,3} \mathbb{D}$, Semra UTKU² ${ }^{\mathbb{D}}$, Mahmut ÜLGER $^{4}$ (D), Gönül ASLAN ${ }^{5}$ (D), Erdoğan BERÇIN ${ }^{6}$}

${ }^{1}$ Mersin University, Vocational School of Health Services, Department of Medical Services and Techniques, 33343, Mersin, Turkey

${ }^{2}$ Mersin University, Faculty of Pharmacy, Department of Pharmaceutical Chemistry, 33160, Mersin, Turkey

${ }^{3}$ Ege University, Faculty of Sciences, Department of Biochemistry, 35040, Izmir, Turkey ${ }^{4}$ Mersin University, Faculty of Pharmacy, Department of Pharmaceutical Microbiology, 33160, Mersin, Turkey

${ }^{5}$ Mersin University, Faculty of Medicine, Department of Medical Microbiology, 33110, Mersin, Turkey ${ }^{6}$ Berçin Pharmacy, Side, 07330, Antalya, Turkey

\begin{abstract}
Objective: Multidrug-resistant pathogenic bacteria, fungi, and Mycobacterium tuberculosis infections continue to be increasingly widespread worldwide. In organic chemistry, the tiya-Michael type addition is also significant reaction in the synthesis of bioactive compounds. In this study, the aim is to synthesize the series of new Michael type addition products 2-amino-3-[(2-nitro-1-phenylpropyl)thio]propanoic acid (IIa-IIg) and to investigate their in vitro, antibacterial, antifungal and antitubercular activity.

Material and Method: IIa-IIg derivatives were performed combining $\beta$-methyl- $\beta$-nitrostyrenes (Ia-Ig) with L-cysteine using Michael addition reaction and characterized by ${ }^{1} H N M R$, FTIR, ESI-LC/MS and elemental analysis. Microdilution method and resazurin microtiter assay were used to determine antimicrobial activities.

Result and Discussion: Comparing the activities of the synthesized compounds, IIa, IId and IIe were found to have significant activity, with a MIC value of $1.95 \mu \mathrm{g} / \mathrm{ml}$, against Mycobacterium tuberculosis H37Rv strain.
\end{abstract}

\footnotetext{
* Corresponding Author/Sorumlu Yazar: Gül Bayram e-mail / e-posta: gulbayram78@ @mail.com, Phone/ Tel.: +903243412815
} 

All synthesized novel compounds displayed moderate activity against tested bacterial and fungi strains. Among
the synthesized compounds, IIb exhibited the best antibacterial and antifungal activity, with MIC values of
$31.25,31.25$ and $15.6 \mu \mathrm{g} / \mathrm{ml}$, against B. subtilis, E. faecium and C. albicans, respectively. It was clear that some
of the synthesized compounds exhibited antimycobacterial activity which could be a very good candidate for
clinical uses.
$\quad$ Keywords: Antibacterial activity, antifungal activity, antimycobacterial activity, $\beta$-methyl- $\beta$-nitrostyrene,
Michael type addition

\section{ÖZ}

Amaç: Çoklu ilaca dirençli patojenik bakteri, mantar ve Mycobacterium tuberculosis enfeksiyonları dünya çapında giderek yaygınlaşmaya devam etmektedir. Organik kimyada, tiya-Michael tipi katım ayrıca biyoaktif bileşiklerin sentezinde önemli bir reaksiyondur. Bu çalışmada, 2-amino-3-[(2-nitro-1fenilpropil)tiyolpropanoik asit Michael tip yeni katım ürünlerinin (IIa-IIg) sentezi ve antibakteriyel, antifungal ve antitüberküler aktivitelerinin araştırlması amaçlanmıştır.

Gereç ve Yöntem: L-sistein ile $\beta$-metil- $\beta$-nitrostirenlerdenin (Ia-Ig) Michael katım reaksiyonu kullanilarak IIa-IIg türevleri sentezlenmiş ve yapllarl ${ }^{l} H N M R$, FTIR, ESI-LC/MS ve elemental analiz ile karakterize edilmiștir. Mikrodilüsyon yöntemi ve resazurin mikrotitre deneyi antimikrobiyal aktivitelerinin belirlenmesinde kullanılmıştır.

Sonuç ve Tartışma: Sentezlenen bileşiklerin aktiviteleri karşılaştırıldı̆̆ında, IIa, IId ve IIe Mycobacterium tuberculosis H37Rv suşuna karşı, $1.95 \mu \mathrm{g} / \mathrm{ml}$ 'lik MIC değeri ile dikkat çekici aktiviteye sahip olarak bulunmuştur. Yeni sentezlenen bileşiklerin hepsi test edilen bakteri ve mantar suşlarına karşı orta derecede aktivite göstermişlerdir. Sentezlenen bileşikler arasında, IIb, B. subtilis, E. faecium ve C. albicans'a karşı sirasiyla 31.25, 31.25 ve $15.6 \mu \mathrm{g} / \mathrm{ml}$ MIC değerleri ile en iyi antibakteryel ve antifungal aktivite sergilemişstir Sentezlenen bazı bileşikler gösterdikleri antimikobakteriyel aktiviteden dolayı klinik kullanım için iyi bir aday olacakları açıktır.

Anahtar kelimeler: Antibakteriyel aktivite, antifungal aktivite, antimikobakteriyel etki, $\beta$-metil- $\beta$ nitrostiren, Michael tip katılim

\section{INTRODUCTION}

The course from drug development to the clinical use of antimicrobials might be one of the substantial successes in the modern history of medicine [1,2]. Despite all the crucial outcomes of antimicrobials in maintaining lives against infections, over the years their treatment has slightly started becoming ineffective due to the development of resistance in these pathogens [3]. Furthermore, antitubercular drugs have been reduced their efficacy in different parts of the globe in particular underdeveloped regions. A recent report published by World Health Organization revealed that tuberculosis is one of the top 10 leading causes of mortality and 10 million people suffering from tuberculosis and 1.4 million have died. [4]. Also, the global spread of COVID-19 is expected to have catastrophic effects on tuberculosis incidence and mortality by 2020 in several countries. To search for the new effective antimicrobial agent, either altering or increasing the existing ones, has been a great prime concern as a result of the rapid outspread of multidrug-resistant pathogens [5, 6].

The $\beta$-nitrostyrene has attracted researchers in recent years because it has become well-known to be a central pharmacophore for various drug candidates [7-13]. Furthermore, the addition products with a $\beta$-nitrostyrene moiety have been accepted to have various pharmacological activities, especially antimicrobial and anticancer [7, 14-17]. 
L-cysteine, a sulfur-bearing amino acid, is mostly found in the structure-activity of proteins and enzymes, which plays an important role in detoxification in biological systems and also, potency on cellular activities such as signal proliferation, differentiation, and apoptosis $[18,19]$. Over the last few years, plenty of compounds selectively evolved with the capability to alter cysteine residue in proteins and enzymes have been made, having pledge in the domain of drug design and the development of pesticides [18].

Therefore, Ia-Ig derivatives containing L-cysteine is believed to have a great potency against resistant pathogens. To achieve this, the Michael addition reaction will take place where Ia-Ig, considered as Michael acceptor, has a strong electron-withdrawing from the nitro group and thiol of L-cysteine under mild reacting conditions [20,21].

Considering the results of our studies [15-17] and the evaluation of the literature survey, the aim of the present work is to synthesis substituted $\beta$-methyl- $\beta$-nitrostyrene considered as pharmacophore and Michael type addition products with L-cysteine for evaluating the antibacterial, antifungal and antimycobacterial activities.

\section{MATERIAL AND METHOD}

\section{Chemistry}

All chemicals and solvents used were of reagent grade (Merck or Aldrich). IR spectra were obtained using a Perkin Elmer Spectrum FT-IR/NIR spectrometer equipped with a Universal ATR Sampling Accessory. Elemental analyses were performed with LECO 932 CHNS analyzer, ${ }^{1} \mathrm{H}$ NMR spectra were recorded in DMSO- $\mathrm{d}_{6}$ (Merck) on a Varian Mercury 400 MHz FT-NMR spectrometer using tetramethylsilane as the internal standard and ESI-LC/MS spectra were taken on a Water Micromass ZQ connected with Waters Alliance HPLC, using ESI (+) or ESI (-) methods. Thin layer chromatography (TLC) was performed on precoated Silica Gel 60 F254 aluminum plates (Merck). Melting points of Ia-Ig and IIa-IIg derivatives were determined in Electrothermal 9200 melting point apparatus and the values were not corrected.

\section{Synthesis of $\beta$-methyl- $\beta$-nitrostyrene (Ia-Ig) derivatives}

The Ia-Ig compounds are well-known compounds that have been previously synthesized by many researchers. In this study, it was synthesized by us with the method given in the literature. ${ }^{10}$ Briefly, the Ia-Ig derivatives were synthesized by refluxing the nitroethane and suitable aromatic aldehyde derivatives in acetic acid and ammonium acetate catalyst for 5 hours as shown in Figure 1. End of the reaction was determined using TLC, the final products were ultimately cooled out by pouring in iced water. Then, the obtained precipitate was crystallized from ethanol. 


\section{Synthesis of 2-amino-3-[(2-nitro-1-phenylpropyl)thio]propanoic acid (IIa-IIg) derivatives}

The synthesis of IIa-IIg derivatives took place following Michael addition reaction, where 0.05 mol L-cysteine with $0.05 \mathrm{~mol}$ appropriate Ia-Ig derivatives were dissolved in (10-15 mL) ethanol and the reaction was maintained stirred at room temperature for 3-4 hours as shown in Figure 1. The ending reaction was pointed out using TLC and the precipitate was filtered and washed using cold ethanol for several times.<smiles>[R]c1ccc(C=O)cc1</smiles><smiles>CC(=O)O[Na]</smiles><smiles>NC(CS)C(=O)O</smiles><smiles>[R]c1cccc(/C=C(\C)[N+](=O)[O-])c1</smiles><smiles>CCCCCCCC</smiles><smiles>[R]c1ccc(C(SCC(N)O)C(C)[N+](=O)[O-])cc1</smiles>

$$
\mathrm{R}=\mathrm{H}, 4-\mathrm{OCH}_{3}, 4-\mathrm{CH}_{3}, 4-\mathrm{Cl}, 4-\mathrm{OH} \text { and } 3-\mathrm{OCH}_{3}, 4-\mathrm{NO}_{2}, 4-\mathrm{N}\left(\mathrm{CH}_{3}\right)_{2}
$$

IIa - IIg

Figure 1. Synthesis of $\beta$-methyl- $\beta$-nitrostyrene and 2-amino-3-[(2-nitro-1-phenylpropyl)thio] propanoic acid derivatives.

2-Amino-3-[(2-nitro-1-phenylpropyl)sulfanyl]propanoic acid (2a)

Yield: 74\%; m.p.: $183{ }^{\circ} \mathrm{C}$; FTIR-ATR: 3249 (N-H), 3031 (aromatic C-H), 1617, 1583, 1418 (COO and aromatic $\mathrm{C}=\mathrm{C}), 1545,1343\left(\mathrm{NO}_{2}\right) \mathrm{cm}^{-1} ;{ }^{1} \mathrm{H}$ NMR (DMSO-d $\left.\mathrm{d}_{6}\right): \delta 1.30\left(3 \mathrm{H}, \mathrm{d}, \mathrm{J}=6.7 \mathrm{~Hz}, \mathrm{CH} H_{3}\right.$, 2.64-2.75 (2H, m, -CH2-S-), 3.10-3.12 (m, 1H, -CH-COO-), 4.49 (1H, d, J= 4.8 Hz, -CH-S-), 5.15-5.19 (m, $1 \mathrm{H},-\mathrm{CH}-\mathrm{NO}_{2}$ ), 7.26-7.41 (m, 5H, $\mathrm{ArH}$ ) ppm; HRMS calcd. for $\mathrm{C}_{12} \mathrm{H}_{17} \mathrm{~N}_{2} \mathrm{O}_{4} \mathrm{~S}[\mathrm{M}+\mathrm{H}]^{+}:$: 285.3393. Found 285.3395. Anal. calcd. for $\mathrm{C}_{12} \mathrm{H}_{16} \mathrm{~N}_{2} \mathrm{O}_{4} \mathrm{~S} . \mathrm{H}_{2} \mathrm{O}$ : C, 47.67; H, 6.00; N, 9.27; S, 10.61. Found: C, $47.65 ; \mathrm{H}, 5.85 ; \mathrm{N}, 9.44 ; \mathrm{S}, 10.86$.

\section{2-Amino-3-\{[1-(4-methoxyphenyl)-2-nitropropyl]sulfanyl\}propanoic acid (2b)}

Yield: 33\%; m.p.: $174{ }^{\circ} \mathrm{C}$; FTIR-ATR: $3231(\mathrm{~N}-\mathrm{H}), 3029$ (aromatic C-H), 1594, 1514, 1425 (COO and aromatic $\mathrm{C}=\mathrm{C}), 1545,1391\left(\mathrm{NO}_{2}\right) \mathrm{cm}^{-1} ;{ }^{1} \mathrm{H}$ NMR (DMSO-d $)$ : $\delta 1.29(3 \mathrm{H}, \mathrm{d}, \mathrm{J}=6.8 \mathrm{~Hz}, \mathrm{CH})$, 2.49-2.69 (2H, m, - $\left.\mathrm{CH}_{2}-\mathrm{S}-\right)$, 3.08-3.12 (m, 1H, -CH-COO-), 3.74 (3H, d, Ar-OCH, $\left.\mathrm{J}=6.8 \mathrm{~Hz}\right), 4.44(1 \mathrm{H}$, $\mathrm{d}, \mathrm{J}=4.8 \mathrm{~Hz},-\mathrm{CH}-\mathrm{S}-), 5.11-5.13\left(\mathrm{~m}, 1 \mathrm{H},-\mathrm{CH}-\mathrm{NO}_{2}\right), 6.86-6.92(\mathrm{~m}, 2 \mathrm{H}, \operatorname{Ar} H), 7.26-7.32(\mathrm{~m}, 2 \mathrm{H}, \operatorname{Ar} H)$ 
ppm; HRMS calcd. for $\mathrm{C}_{13} \mathrm{H}_{19} \mathrm{~N}_{2} \mathrm{O}_{5} \mathrm{~S}[\mathrm{M}+\mathrm{H}]^{+}$: 315.3653. Found 315.3650. Anal. calcd. for $\mathrm{C}_{13} \mathrm{H}_{18} \mathrm{~N}_{2} \mathrm{O}_{5} \mathrm{~S} . \mathrm{H}_{2} \mathrm{O}: \mathrm{C}, 46.98 ; \mathrm{H}, 6.07 ; \mathrm{N}, 8.43 ; \mathrm{S}, 9.65$. Found: C, 46.85; H, 5.93; N, 8.64; S, 9.95.

2-Amino-3-\{[1-(4-methylphenyl)-2-nitropropyl]sulfanyl\}propanoic acid (2c)

Yield 77\%; m.p.: 170-171 ${ }^{\circ}$ C; FTIR-ATR: $3220(\mathrm{~N}-\mathrm{H}), 3035$ (aromatic C-H), 1606, 1513, 1418 (COO and aromatic $\mathrm{C}=\mathrm{C}), 1551,1391\left(\mathrm{NO}_{2}\right) \mathrm{cm}^{-1} ;{ }^{1} \mathrm{H}$ NMR (DMSO-d $)$ ): $\delta 1.29\left(3 \mathrm{H}, \mathrm{d}, \mathrm{J}=6.8 \mathrm{~Hz}, \mathrm{CH}_{3}\right)$, $2.28\left(3 \mathrm{H}, \mathrm{s}, \mathrm{Ar}-\mathrm{CH}_{3}, \mathrm{~J}=8 \mathrm{~Hz}\right), 2.61-2.69\left(2 \mathrm{H}, \mathrm{m},-\mathrm{CH}_{2}-\mathrm{S}-\right)$, 3.09-3.11 (m, 1H, -CH-COO-), 4.44 (1H, d, $\mathrm{J}=4.8 \mathrm{~Hz},-\mathrm{C} H-\mathrm{S}-), 5.11-5.15\left(\mathrm{~m}, 1 \mathrm{H}, \mathrm{C} H-\mathrm{NO}_{2}\right), 7.11-7.17(\mathrm{~m}, 2 \mathrm{H}, \mathrm{Ar} H), 7.22-7.27$ (m, 2H, $\mathrm{ArH}$ ) ppm; HRMS calcd. for $\mathrm{C}_{13} \mathrm{H}_{19} \mathrm{~N}_{2} \mathrm{O}_{4} \mathrm{~S} \quad[\mathrm{M}+\mathrm{H}]^{+}:$299.3659. Found 299.3660. Anal. calcd. for $\mathrm{C}_{13} \mathrm{H}_{18} \mathrm{~N}_{2} \mathrm{O}_{4} \mathrm{~S} .1 / 2 \mathrm{H}_{2} \mathrm{O}: \mathrm{C}, 50.80 ; \mathrm{H}, 6.23 ; \mathrm{N}, 9.11 ; \mathrm{S}, 10.43$. Found: C, 50.65; H, 6.11; N, 9.43; S, 10.48 . 2-Amino-3-\{[1-(4-chlorophenyl)-2-nitropropyl]sulfanyl\}propanoic acid (2d)

Yield 79\%; m.p.: $186^{\circ} \mathrm{C}$; FTIR-ATR: 3225 (N-H), 3135 (aromatic C-H), 1610, 1513, 1419 (COO and aromatic $\mathrm{C}=\mathrm{C}), 1552,1389\left(\mathrm{NO}_{2}\right) \mathrm{cm}^{-1} ;{ }^{1} \mathrm{H}$ NMR (DMSO-d 6$): \delta 1.31\left(3 \mathrm{H}, \mathrm{d}, \mathrm{J}=6.4 \mathrm{~Hz}, \mathrm{CH}_{3}\right), 2.62-$ $2.72\left(2 \mathrm{H}, \mathrm{m},-\mathrm{CH}_{2}-\mathrm{S}-\right), 3.10-3.13$ (m, 1H, CH-COO-), 4.53-4.59 (1H, m, CH-S-), 5.18-5.24 (m, 1H, CH$\mathrm{NO}_{2}$ ), 7.38-7.40 (m, 2H, $\left.\mathrm{ArH}\right)$, 7.41-7.43 (m, 2H, $\left.\mathrm{ArH}\right)$ ppm; HRMS calcd. for $\mathrm{C}_{12} \mathrm{H}_{16} \mathrm{ClN}_{2} \mathrm{O}_{4} \mathrm{~S}[\mathrm{M}+\mathrm{H}]^{+}$: 319.7844. Found 319.7845. Anal. calcd. for $\mathrm{C}_{12} \mathrm{H}_{15} \mathrm{ClN}_{2} \mathrm{O}_{4} \mathrm{~S}$ : C, 45.21; H, 4.74; N, 8.79; S, 10.06. Found: C, 45.15; H, 4.70; N, 8.90; S, 10.19.

2-Amino-3-\{[1-(4-hydroxy-3-methoxyphenyl)-2-nitropropyl]sulfanyl\}propanoic acid (2e)

Yield 59\%; m.p.: $176^{\circ} \mathrm{C}$; FTIR-ATR: $3215(\mathrm{~N}-\mathrm{H}), 3049$ (aromatic C-H), 1612, 1584, 1418 (COO and aromatic $\mathrm{C}=\mathrm{C}), 1544,1389\left(\mathrm{NO}_{2}\right) \mathrm{cm}^{-1} ;{ }^{1} \mathrm{H}$ NMR (DMSO-d 6$): \delta 1.30\left(3 \mathrm{H}, \mathrm{d}, \mathrm{J}=6.4 \mathrm{~Hz}, \mathrm{CH}_{3}\right), 2.63-$ $2.71\left(2 \mathrm{H}, \mathrm{m},-\mathrm{CH}_{2}-\mathrm{S}-\right), 3.12-3.15$ (m, 1H, -CH-COO-), $3.76\left(3 \mathrm{H}, \mathrm{s},-\mathrm{OCH}_{3}\right), 4.41-4.36(1 \mathrm{H}, \mathrm{m},-\mathrm{CH}-\mathrm{S}-)$, 5.20-5.11 (m, 1H, -CH-NO $\left.{ }_{2}\right), 6.78-6.68(\mathrm{~m}, 2 \mathrm{H}, \mathrm{ArH}), 6.97-6.91(\mathrm{~m}, 1 \mathrm{H}, \mathrm{ArH}) \mathrm{ppm}$; HRMS calcd. for $\mathrm{C}_{13} \mathrm{H}_{19} \mathrm{~N}_{2} \mathrm{O}_{6} \mathrm{~S}[\mathrm{M}+\mathrm{H}]^{+}:$331.3647. Found 331.3649. Anal. calcd. for $\mathrm{C}_{13} \mathrm{H}_{18} \mathrm{~N}_{2} \mathrm{O}_{6} \mathrm{~S}: \mathrm{C}, 47.26 ; \mathrm{H}, 5.49 ; \mathrm{N}$, 8.48; S, 9.71. Found: C, 47.32; H, 5.56; N, 8.49; S, 9.63.

2-Amino-3-\{[1-(4-nitrophenyl)-2-nitropropyl]sulfanyl\}propanoic acid (2f)

Yield 73\%; m.p.: $178^{\circ} \mathrm{C}$; FTIR-ATR: 3213 (N-H), 3053 (aromatic C-H), 1650, 1525, 1447 (COO and aromatic $\mathrm{C}=\mathrm{C}), 1531,1374\left(\mathrm{NO}_{2}\right) \mathrm{cm}^{-1} ;{ }^{1} \mathrm{H}$ NMR (DMSO-d 6$): \delta 1.34\left(3 \mathrm{H}, \mathrm{d}, \mathrm{J}=6.4 \mathrm{~Hz}, \mathrm{CH}_{3}\right), 2.77-$ 2.64 (2H, m, - $\left.\mathrm{CH}_{2}-\mathrm{S}-\right)$, 3.26-3.21 (m, 1H, -CH-COO-), 4.80-4.72 (1H, m, -CH-S-), 5.40-5.28 (m, 1H, $\mathrm{CH}-\mathrm{NO}_{2}$ ), 7.80-7.68 (m, 2H, ArH), 8.24-8.19 (m, 2H, $\mathrm{ArH}$ ) ppm; HRMS calcd. for $\mathrm{C}_{12} \mathrm{H}_{16} \mathrm{~N}_{3} \mathrm{O}_{4} \mathrm{~S}[\mathrm{M}+\mathrm{H}]^{+}$: 330.3374. Found 330.3378. Anal. calcd. for $\mathrm{C}_{12} \mathrm{H}_{15} \mathrm{~N}_{3} \mathrm{O}_{6} \mathrm{~S}$ : C, 43.76; H, 4.59; N, 12.76; S, 9.74. Found: C, 43.60; H, 4.32; N, 12.90; S, 9.73.

\section{2-Amino-3-(\{1-[4-(dimethylamino)phenyl]-2-nitropropyl\}sulfanyl)propanoic acid (2g)}

Yield 58\%; m.p.: $188^{\circ} \mathrm{C}$; FTIR-ATR: 3217 (N-H), 3053 (aromatic C-H), 1590, 1488, 1447 (COO and aromatic $\mathrm{C}=\mathrm{C}), 1488,1374\left(\mathrm{NO}_{2}\right) \mathrm{cm}^{-1} ;{ }^{1} \mathrm{H}$ NMR (DMSO-d 6$): \delta 1.29\left(3 \mathrm{H}, \mathrm{d}, \mathrm{J}=6.4 \mathrm{~Hz}, \mathrm{CH}_{3}\right), 2.77-$ 
$2.64\left(2 \mathrm{H}, \mathrm{m},-\mathrm{CH}_{2}-\mathrm{S}-\right), 2.89$ (s, 3H, -N $\left.\left(\mathrm{CH}_{3}\right)\right), 3.01$ (s, 3H, -N $\left.\left(\mathrm{CH}_{3}\right)\right),(3.33-3.26$ (m, 1H, -CH-COO-), 4.40-4.34 (1H, m, -CH-S-), 5.09-5.04 (m, 1H, -CH-NO $\left.{ }_{2}\right), 7.18-7.13(\mathrm{~m}, 2 \mathrm{H}, \mathrm{ArH}), 6.81-6.78(\mathrm{~m}, 2 \mathrm{H}$, ArH) ppm; HRMS calcd. for $\mathrm{C}_{14} \mathrm{H}_{22} \mathrm{~N}_{3} \mathrm{O}_{4} \mathrm{~S}[\mathrm{M}+\mathrm{H}]^{+}$: 328.4071. Found 328.4076. Anal. calcd. for $\mathrm{C}_{14} \mathrm{H}_{21} \mathrm{~N}_{3} \mathrm{O}_{4} \mathrm{~S}$ C, 51.36; H, 6.47; N, 12.83; S, 9.79. Found: C, 51.19; H, 6.68; N, 12.74; S, 9.92.

\section{Biological Activity}

\section{Antibacterial and Antifungal Activity Methods}

To determine the minimum inhibitory concentrations of antibacterial and antifungal activities of IIa-IIg derivatives; Gram-positive and negative bacteria and Candida species were tested using the American Type Culture Collection (ATCC) reference species. Ampicilline. $3 \mathrm{H}_{2} \mathrm{O}$ and fluconazole were used as reference compounds in antibacterial and antifungal activity test, respectively. All the tested isolates were reference strains. Hence, ethical approval was not required.

Modified serial microdilution method was applied in antibacterial and antifungal tests of IIa-IIg derivatives [22, 23]. Lyophilized bacterial strains and fungal strains were subcultured in Mueller-Hinton Agar at $37{ }^{\circ} \mathrm{C}$ for $24 \mathrm{~h}$ and sabouraud dextrose agar at $28{ }^{\circ} \mathrm{C}$ for $24 \mathrm{~h}$, respectively. Stock solutions of each compound to be tested were prepared at $1000 \mu \mathrm{g} / \mathrm{ml}$ in $\mathrm{DMSO} / \mathrm{H}_{2} \mathrm{O}(50 \%)$. All compound's stock solutions and reference compounds were prepared at 500, 250 125, 62.5, 31.25, 15.62, 7.82, 3.9, 1.95, 0.97 and $0.48 \mu \mathrm{g} / \mathrm{ml}$. The suspensions of the bacteria and fungi strains were prepared in normal saline solution. The turbidity was adjusted to 0.5 Mcfarland with an absorbance of $0.08-0.13$ at $625 \mathrm{~nm} .100 \mu \mathrm{L}$ Mueller-Hinton Broth (MHB) or Tryptic Soy broth used in the antibacterial or antifungal activity test were added to only 11 wells of plates with 96 -well plates. A $100 \mu \mathrm{L}$ of tested compound liquor was added to the first well and then two fold dilutions were performed. The microorganism suspension was added to each well except for the last row and then incubated at $37^{\circ} \mathrm{C}$ for $24 \mathrm{~h}$ for antimicrobial and $28^{\circ} \mathrm{C}$ for 24 $\mathrm{h}$ for antifungal activities. At the end of the incubation period, minimum inhibitory concentration (MIC) values were evaluated by spectrophotometer at $450 \mathrm{~nm}$ in all plates. Biological activity tests were carried out duplicate independently according to literature.

\section{Antimycobacterial Activity Methods}

The antitubercular activities of IIa-IIg derivatives were tested according to the REMA plate technique with minor modifications [24, 25]. As a standard strain, M. tuberculosis $\mathrm{H} 37 \mathrm{Rv}$ was used and ensured from the National Tuberculosis Reference Laboratory, Ankara, Turkey. Lowenstein-Jensen medium was used for maintenance of Mycobacterium tuberculosis strain H37Rv.

In REMA technique, Middlebrook 7H9-S broth (Difco), supplemented with $0.5 \%$ glycerol, $0.1 \%$ casitone and $10 \%$ oleic acid-albumin-dextrose-catalase was used as a subculturing medium at $37^{\circ} \mathrm{C}$ for 7 10 days until the turbidity of the supernatant was adjusted to McFarland standard No.1 A solution of $0.01 \%$ resazurin sodium salt (Sigma R7017) was prepared with distilled water and then sterilized using a 
$0.22 \mu \mathrm{m}$ membrane filter (Ministar, Sartorius, Germany) was kept at $4^{\circ} \mathrm{C}$. The compounds IIa-IIg and were dissolved in DMSO/ $\mathrm{H}_{2} \mathrm{O}(50 \%$ ) at a concentration of $1000 \mu \mathrm{g} / \mathrm{ml}$. Rifampicin (Sigma, R3501) and isoniazid (Sigma, I3377) were used as reference antitubercular agents. Test compounds were sterilized using a $0.22 \mu \mathrm{m}$ membrane filter followed by serial two fold dilutions tested in a 96-well microtiter plate. $100 \mu \mathrm{L}$ compound and $100 \mu \mathrm{L}$ Middlebrook 7H9-S broth suspension were performed each well. To each plate was added a growth control without test compound and a sterility control without inoculum. The test concentration ranges of the newly synthesized and reference compounds were used as 500-0.12 g/ml. Plates were incubated $37^{\circ} \mathrm{C}$ in a normal atmosphere for 7 days. After incubation was completed, $30 \mu 1$ resazurin was added to all wells and then microtiter plates were incubated for $24 \mathrm{~h}$ at $37^{\circ} \mathrm{C}$. The MIC value was determined by evaluating the lowest suspension concentration that inhibited the color change of resazurin. Antitubercular activity test was performed in duplicate independently according to literature.

\section{RESULT AND DISCUSSION}

Ia-Ig and target compound IIa-IIg derivatives were prepared by a nitro aldol condensation and Michael addition reaction, respectively. Ia-Ig were synthesized by the reaction of nitroethane and benzaldehyde derivatives with the same nitroaldol condensation pattern of the intended product, using ammonium acetate as catalyst (Figure 1) [10]. The final compounds were obtained by the reaction of the Ia-Ig derivatives with L-cysteine. The results of the experimental processes of these newly synthesized compounds have shown that the average/high level of consideration is reached as can be seen in the experimental section.

The final products (IIa-IIg) and their structures outlined in Figure 1 were identified by FT-IR, ${ }^{1} \mathrm{H}$ NMR, ESI-LC/MS spectroscopic techniques. The elemental analysis data for IIa-IIg derivatives were found to be consistent with the proposed empirical formula. In the IR spectrum, the concrete characteristic was described at $\mathrm{N}-\mathrm{H}, \mathrm{NO}_{2}, \mathrm{COO}-$ and $\mathrm{C}=\mathrm{C}$ stretching bands at $3215-3249,1374-1545 \mathrm{~cm}^{-1}$ and 1418 $1650 \mathrm{~cm}^{-1}$, respectively and the ${ }^{1} \mathrm{H}$ NMR and ESI-L/MS spectra were shown in the experimental section. These spectral and elemental analyses data described the purity and structure of desired compounds.

When the ${ }^{1} \mathrm{H}$ NMR spectra of the final products, it was found that the chemical shift values and hydrogen numbers were consistent with the corresponding protons. It should also be noted that for IIa-IIg diastereomeric compounds, it was observed that $-\mathrm{CH}_{2}-\mathrm{S}$ - protons were coupled with $-\mathrm{CH}$-COO- protons and appeared as multiplets were seen in the experimental section. These observations were consistent with those reported in the literature $[16,26,27]$. The retention times of the peak in the samples and the ESILC/MS spectrum are evidence that IIa-IIg is pure and suggested chemical structures. The findings obtained from this spectral analysis indicate that the newly synthesized compounds have the desired purity and chemical structure. 
It can be estimated that the compound with three chiral centers is quite difficult to separate diastreomers. Therefore the Michael addition products of L-cysteine with Ia-Ig derivatives are an asymmetric process because two novel chiral centers were created, namely, $\alpha$ and $\beta$ carbon atom in the starting materials. Therefore, configurational diastereomers that are thought to have high pharmacological activity will be synthesized as organocatalytic diastereo- and enantioselective Sulfa-Michael addition products in later studies.

The biological properties such as antimicrobial, antifungal and antimycobacterial activities of IIaIIg derivatives were tested against four Gram-positive and five Gram-negative bacteria, four fungi species and $M$. tuberculosis $\mathrm{H} 37 \mathrm{Rv}$ using the microdilution broth method and REMA according to recommendations techniques [22-25]. Ampicilline. $3 \mathrm{H}_{2} \mathrm{O}$, fluconazole, isoniazid and rifampicin were used as a reference in antibacterial, antifungal and antimycobacterial activity test, respectively (Table 1 and 2). A comparison of the activities of synthesized compounds IIa-IIg showed that compound IIb, with a methoxy substituent, was the most potent compound, with MIC value of $31.25 \mu \mathrm{g} / \mathrm{ml}$ versus B. subtilis, E. faecium. Compounds IIa, IIc-IIg with a MIC of $62.50 \mu \mathrm{g} / \mathrm{ml}$ were found to have the same activity as ampicilline. $3 \mathrm{H}_{2} \mathrm{O}$ against $E$. faecium. Compounds IIb and IId exhibited significant antifungal activity with MIC value of $15.16 \mu \mathrm{g} / \mathrm{ml}$ against $C$. albicans which were comparable with fluconazole as a reference drug. It is well known that the antifungal drug fluconazole is used clinically to treat or suppress various infections [28]. This result suggests that compound IIb may be worth further study in terms of their antifungal activity. We will continue our investigations to determine in vivo antifungal and antibacterial activities of compound IIb.

Table 2 outlines the in vitro results of antimycobacterial activities for the synthesized compounds (IIa-IIg), determined as MIC values. All compounds were considerably found to hold a significant activity against $M$. tuberculosis H37Rv strains. The lowest MIC value was observed from compounds IIa, IId and IIe with $1.95 \mu \mathrm{g} / \mathrm{ml}$ whereas the intermediate expressed by IIb, IIc, and IIf were 3.9, 7.81 and 7.81 ug/ml, respectively. Compound IIg with a MIC value of $31.25 \mu \mathrm{g} / \mathrm{ml}$ was found to be the least active compound in the compounds tested against M. tuberculosis H37Rv.

Having said that $\beta$-nitrostyrene has become a pharmacophore in drug design, this potential action may be observed throughout the structural conformation and physicochemical properties belonging to the ring and nitrovinyl $[10,12,29]$. $\beta$-nitrostyrene derived from electron withdrawal or donating aromatic substitutions to the $o, m$ or $p$ position showed the antimicrobial activity $[8,29]$. Negative mesomeric effect of nitro group in nitro-vinyl structure gives to the benzylic position a partial positive charge and thus also the ability to react as electron accepting feature. So benzylic carbon reacts as the electron accepting centre from any nucleophiles in the michael addition reaction. The bond formed by the sulfur and benzylic carbon in the addition product is stable enough to reach the acting site, after that it is effective enough to 
change structurally the important proteins in microorganisms. Probably it reacts with the nucleophilic groups of proteins in the microorganism and transports the cysteine molecule to the protein.

Recent studies showing that L-cysteine carries various activities to cellular functions have made it easy to explain why L-cysteine modified compounds show higher activity. This screening might have an impact on increasing antimicrobial activity. Therefore, considering the previous studies on $\beta$ nitrostyrene derivatives without L-cysteine, these compounds have shown a tremendous effect on tested strains.

Table 1. Antibacterial and antifungal activity of IIa-IIg derivatives against reference bacteria and fungus strains

\begin{tabular}{|l|l|l|l|l|l|l|l|l|l|l|l|l|l|}
\hline $\begin{array}{l}\text { Compd. } \\
\mathbf{R}\end{array}$ & A & $\mathbf{B}$ & $\mathbf{C}$ & $\mathbf{D}$ & $\mathbf{E}$ & $\mathbf{F}$ & $\mathbf{G}$ & $\mathbf{H}$ & $\mathbf{I}$ & $\mathbf{J}$ & $\mathbf{K}$ & $\mathbf{L}$ & $\mathbf{M}$ \\
\hline $\begin{array}{l}\mathrm{IIa}, \\
4-\mathrm{H}\end{array}$ & 125 & 62.5 & 125 & 125 & 125 & 62.5 & 125 & 125 & 125 & 31.25 & 62.5 & 125 & 250 \\
\hline $\begin{array}{l}\mathrm{IIb}, \\
4-\mathrm{OCH}\end{array}$ & 31.25 & 31.25 & 62.5 & 125 & 125 & 62.5 & 125 & 125 & 125 & 15.6 & 31.25 & 125 & 125 \\
\hline $\begin{array}{l}\mathrm{IIc}, \\
4-\mathrm{CH}_{3}\end{array}$ & 125 & 62.5 & 125 & 125 & 125 & 62.5 & 125 & 125 & 125 & 125 & 125 & 125 & 125 \\
\hline $\begin{array}{l}\mathrm{IId}, \\
\text { 4-Cl }\end{array}$ & 125 & 62.5 & 62.5 & 125 & 125 & 62.5 & 125 & 125 & 125 & 15.6 & 62.5 & 125 & 250 \\
\hline $\begin{array}{l}\text { IIe, } \\
4-\mathrm{OH}- \\
3-\mathrm{OCH}\end{array}$ & 125 & 62.5 & 125 & 125 & 125 & 62.5 & 125 & 125 & 125 & 125 & 62.5 & 125 & 250 \\
\hline $\begin{array}{l}\text { IIf, } \\
\text { 4-NO }\end{array}$ & 125 & 62.5 & 125 & 125 & 125 & 62.5 & 125 & 125 & 125 & 125 & 125 & 125 & 125 \\
\hline $\begin{array}{l}\text { IIg, } \\
4-\mathrm{N}\left(\mathrm{CH}_{3}\right)_{2}\end{array}$ & 125 & 62.5 & 125 & 125 & 125 & 62.5 & 125 & 125 & 62.5 & 250 & 250 & 125 & 125 \\
\hline Amp. & $<0.48$ & 62.5 & $<0.48$ & 31.25 & 7.8 & $<0.48$ & 31.25 & 7.8 & 31.25 & $*$ & $*$ & $*$ & $*$ \\
\hline Fluc. & $*$ & $*$ & $*$ & $*$ & $*$ & $*$ & $*$ & $*$ & $*$ & 31.25 & $<0.48$ & $<0.48$ & $<0.48$ \\
\hline
\end{tabular}

A: Bacillus subtilis subsp. subtilis (ATCC 6051), B: Enterococcus faecium (VanR QC set ATCC 700221), C: Staphylococcus aureus (ATCC 29213), D: Enterobacter hormaechei (ATCC 700323), E: Klebsiella pneumonia (ATCC 27736), F: Acinetobacter baumannii (ATCC 49139), G: Pseudomonas aeruginosa (ATCC 27853), H: Escherichia coli O157:H7 (ATCC 35150), I: Stenotrophomonas maltophilia (ATCC 17666), J: Candida albicans (ATCC 14053), K: Candida glabrata (ATCC 15126), L: Candida parapsilosis (ATCC 22019), M: Candida tropicalis (ATCC 1969), Amp: Ampicilline. $3 \mathrm{H}_{2} \mathrm{O}$, Fluc: Fluconazole. *: Not tested.

Table 2. Antitubercular activity of IIa-IIg derivatives against M. tuberculosis H37Rv

\begin{tabular}{|l|l|}
\hline Compd., $\mathbf{R}$ & MIC $(\boldsymbol{\mu g} / \mathbf{m l})$ \\
\hline IIa, $4-\mathrm{H}$ & 1.95 \\
\hline $\mathrm{IIb}, 4-\mathrm{OCH}_{3}$ & 3.9 \\
\hline $\mathrm{IIc}, 4-\mathrm{CH}_{3}$ & 7.81 \\
\hline IId, $4-\mathrm{Cl}$ & 1.95 \\
\hline IIe, $4-\mathrm{OH}, 3-\mathrm{OCH}_{3}$ & 1.95 \\
\hline IIf, 4-NO $\mathrm{NO}_{2}$ & 7.81 \\
\hline IIg, 4-N $\left(\mathrm{CH}_{3}\right)_{2}$ & 31.25 \\
\hline Isoniazid & 0.12 \\
\hline Rifampicin & 0.97 \\
\hline
\end{tabular}

Drug resistance has increasingly affected the clinically used antibiotics which weakened the efficiency of treatment against infections. Working on the novel antimicrobial agent is a preliminarily 
concerned issue for the researchers for fighting the problem. In this regard, the newly synthesized Michael-type addition products IIa-IIg compounds displayed relevant preliminary activity which motivates us to move forward for achieving the main goal.

\section{ACKNOWLEDGMENTS}

This work was supported by the Mersin University Scientific Research Funds (Grant number 2018-1-AP2-2782).

\section{AUTHOR CONTRIBUTIONS}

Conception: G.B., S.U., E.B.; Design: G.B., A.N., S.U., M.Ü., G.A., E.B.; Supervision: G.B., A.N., S.U., M.Ü.; Resources: G.B., S.U., G.A.; Materials: G.B., S.U., M.Ü., G.A.; Data collection and/or processing: G.B., A.N., S.U., M.Ü., G.A.; Analysis and/or interpretation: G.B., A.N., S.U., M.Ü.; Literature search: G.B., A.N., S.U.; Writing manuscript: G.B., A.N., S.U., M.Ü., G.A., E.B.; Critical review: G.B., A.N., S.U., M.Ü., G.A., E.B.; Other: -

\section{CONFLICT OF INTEREST}

The authors declare no conflict of interest.

\section{REFERENCES}

1. Gajdacs, M. (2019). The concept of an ideal antibiotic: implications for drug design. Molecules, 24, 1-16. https://doi.org/10.3390/molecules24050892

2. Gajdacs, M., Albericio, F. (2019). Antibiotic resistance: from the bench to patients. Antibiotics, 8 , 1-4. https://doi.org/10.3390/antibiotics8030129

3. Laxminarayan, R., Duse, A., Wattal, C., Zaidi, A.K.M, Wertheim, H.F.L., Sumpradit, N., Vieghe, E., Hara, G.L., Gould, I.M., Goossens, H., Greko, C., So, A.D., Bigdeli, M., Tomson, G., Woodhouse, W., Ombaka, E., Peralta, A.Q., Qamar, F.N., Mir, F., Kariuki, S., Bhutta, Z.A., Coates, A., Bergstrom, R., Wright, G.D., Brown, E.D., Cars, O. (2013). Antibiotic resistance-the need for global solutions. Lancet Infectious Disease, 13, 1057-1098. https://doi.org/10.1016/S1473-3099 (13)70318-9

4. World Health Organization Web Site. (2020). Retrieved January 14, 2021, from https://apps.who.int/iris/bitstream/handle/10665/336069/9789240013131-eng.pdf

5. Nielsen, S.F., Boesen, T., Larsen, M., Schonning, K., Kromann, H. (2004). Antibacterial chalcones-bioisosteric replacement of the 4'-hydroxy group. Bioorganic \& Medicinal Chemistry, 12, 30473054. https://doi.org/10.1016/j.bmc.2004.03.071 
6. Narasimhan, B., Belsare, D., Pharande, D., Mourya, V., Dhake, A. (2004). Esters, amides and substituted derivatives of cinnamic acid: synthesis, antimicrobial activity and QSAR investigations. European Journal of Medicinal Chemistry, 39, 827-834. https://doi.org/10.1016/j.ejmech.2004.06.013

7. Kaap, S., Quentin, I., Tamiru, D., Shaheen, M., Eger, K., Steinfelder, H.J. (2003). Structure activity analysis of the pro-apoptotic, antitumor effect of nitrostyrene adducts and related compounds. Biochemical Pharmacology, 65, 603-610. https://doi.org/10.1016/s0006-2952(02)01618-0

8. Mikami, Y., Yazawa, K., Maeda, A., Uno, J., Kubo, A., Saito, N., Kawakami, N. (1991). Antifungal activity of SL-1, a beta-nitrostyrene type pigment and its synthetic congeners. Journal of Antibiotics (Tokyo), 44, 1454-1456. https://doi.org/10.7164/antibiotics.44.1454

9. Wang, W.Y., Wu, Y.C., Wu, C.C. (2006). Prevention of platelet glycoprotein IIb/IIIa activation by 3,4methylenedioxy- $\beta$-nitrostyrene, a novel tyrosine kinase inhibitor. Molecular Pharmacology, 70, 1380 1389. https://doi.org/10.1124/mol.106.023986

10. Milhazes, N., Calheiros, R., Marques, M.P., Garrido, J., Cordeiro, M.N., Rodrigues, C., Cordeiro, M.N.D.S., Rodrigues, C., Quinteira, S., Novais, C., Peixe, L., Borges, F. (2006). $\beta$-Nitrostyrene derivatives as potential antibacterial agents: a structure-property-activity relationship study. Bioorganic \& Medicinal Chemistry, 14, 4078-4088. https://doi.org/10.1016/j.bmc.2006.02.006

11. Hsieh, P.W., Chang, Y.T., Chuang, W.Y., Shih, H.C., Chiang, S.Z., Wu, C.C. (2010). The synthesis and biologic evaluation of anti-platelet and cytotoxic $\beta$-nitrostyrenes. Bioorganic \& Medicinal Chemistry, 18, 7621-7627. https://doi.org/10.1016/j.bmc.2010.08.039

12. Cornell, H., Nguyen, T., Nicoletti, G., Jackson, N., Hügel, H. (2014). Comparisons of halogenated $\beta$-nitrostyrenes as antimicrobial agents. Applied Sciences, 4, 380-389. https://doi.org/10.3390/app4030380

13. Villar, J.A.F.P., Lima, F.T.D., Veber, C.L., Oliveira, A.R.M., Calgarotto, A.K., Marangoni, S., Silva, S.L. (2008). Synthesis and evaluation of nitrostyrene derivative compounds, new snake venom phospholipase A2 inhibitors. Toxicon, 51, 1467-1478. https://doi.org/10.1016/j.toxicon.2008.03.023.

14. Rahmani-Nezhad, S., Safavi, M., Pordeli M., Ardestani, S.K., Khosravani, L., Pourshojaei, Y., Emami, M. S., Foroumadi, A., Shafiee, A. (2014). Synthesis, in vitro cytotoxicity and apoptosis inducing study of 2-aryl-3-nitro-2H-chromene derivatives as potent anti-breast cancer agents. European Journal of Medicinal Chemistry, 86, 562-569. https://doi.org/10.1016/j.ejmech.2014.09.017

15. Gokce, M., Ozcelik, B., Bakır, G., Karaoğlu, T., Bercin, E., Noyanalpan, N. (2004). Antiviral and antimicrobial activities of new nitrobutane derivatives. Arzneimittel-Forschung, 54, 891-897. https://doi.org/10.1055/s-0031-1297045

16. Gokce, M., Utku, S., Bercin, E., Özcelik, B., Karaoglu, T., Noyanalpan, N. (2005). Synthesis and in vitro antimicrobial and cytotoxicity activities of 2-[(2-nitro-1-phenylalkyl) thio] benzoic acid derivatives. Turkish Journal of Chemistry, 29, 207-217.

17. Utku, S., Gokce, M., Ozcelik, B., Bercin, E. (2008). Evaluation of antimicrobial activity of 2-[(2nitro-1-phenylalkyl)thiomethyl] benzimidazole derivatives. Turkish Journal of Pharmaceutical Sciences, 5, 107-116. 
18. Shi, Y., Carroll, K.S. (2020). Activity-based sensing for site-specific proteomic analysis of cysteine oxidation. Accounts of Chemical Research, 53, 20-31. https://doi.org/ 10.1021/acs.accounts.9b00562

19. Piste, P. (2013). Cysteine-master antioxidant. International Journal of Pharmaceutical, Chemical and Biological Sciences, 3, 143-149. https://doi.org/10.3329/jbsp.v2i0.978

20. Sobhani, S., Rezazadeh, S. (2010). Michael addition reaction of thioacetic acid (AcSH) to conjugated alkenes under solvent- and catalyst-free conditions. Phosphorus, Sulfur, and Silicon and the Related Elements, 185, 2076-2084. https://doi.org/10.1080/10426500903496713

21. Pei, Q. L., Han, W. Y., Wu, Z. J., Zhang, X. M., \& Yuan, W. C. (2013). Organocatalytic iastereoand enantioselective sulfa-Michael addition to $\alpha, \quad \beta$-disubstituted nitroalkenes. Tetrahedron, 69(26), 5367-5373. https://doi.org/10.1016/j.tet.2013.04.125

22. Clinical and Laboratory Standards Institute (CLSI) (formerly NCCLS). (2008). Performance Standards for Antimicrobial Susceptibility Testing 18th Informational Supplement. CLSI M100S18, Clinical and Laboratory Standards Institute, 940 West Valley Road, Wayne, Pennsylvania, USA.

23. Clinical and Laboratory Standards Institute (CLSI) (formerly NCCLS). (2006). Reference Method for Broth Dilution Antifungal Susceptibility Testing of Yeast Approved Standard, M27-A3, Clinical and Laboratory Standards Institute, 940 West Valley Road, Wayne, Pennsylvania, USA.

24. National Committee for Clinical Laboratory Standards. (2003). Susceptibility Testing of Mycobacteria, Nocardia, and Other Aerobic Actinomycetes: Approved Standard NCCLS Document M24-A. Wayne, Pennsylvania.

25. Nateche, F., Martin, A., Baraka, S., Palomino, J.C., Khaled, S., Portaels, F. (2006). Application of the resazurin microtitre assay for detection of multidrug resistance in Mycobacterium tuberculosis in Algiers. Journal of Medical Microbiology, 55, 857-860. https://doi.org/10.1099/jmm.0.46513-0

26. Bercin, E., Ozguçlu, S. (2005). The addition products of $\beta$-methyl- $\beta$-nitrostyrene derivatives with 2-mercaptomethylbenzimidazole and their NMR studies. Journal of Faculty of Pharmacy Gazi, 13, $133-142$.

27. Demir-Ordu, O., Demir-Dundar, H., Ozkirimli, S. (2015). Stereochemical Investigations of diastereomeric N-[2-(aryl)-5-methyl-4-oxo-1,3-thiazlidine-3-yl]-pyridine-3-carboxamide by nuclear magnetic resonance spectroscopy (1D and 2D). International Journal of Spectroscopy, 19. https://doi.org/10.1155/2015/609250

28. Shafiei, M., Peyton, L., Hashemzadeh, M., Foroumadi, A. (2020). History of the development of antifungal azoles: A review on structures, SAR, and mechanism of action. Bioorganic Chemistry, 104, 104240. https://doi.org/10.1016/j.bioorg.2020.104240

29. Pettit, R.K., Pettit, G.R., Hamel, E. Hamel, Hogan, F., Moser, B.R., Wolf, S., Pon, S., Chapuis, J.C., Schmidt, J.M. (2009). E-combretastatin and E-resveratrol structural modifications: Antimicrobial and cancer cell growth inhibitory $\beta$-E-nitrostyrenes. Bioorganic \& Medicinal Chemistry, 17, 6606-6612. https://doi.org/10.1016/j.bmc.2009.07.076 